\title{
Proguanil Hydrochloride
}

National Cancer Institute

\section{Source}

National Cancer Institute. Proguanil Hydrochloride. NCI Thesaurus. Code C47690.

The hydrochloride salt form of proguanil, a synthetic biguanide derivative of pyrimidine and an folate antag onist with antimalarial property. Upon hydrolysis, proguanil is converted to its active cyclic triazine metabolite, cycloguanil, by a cytochrome P450 dependent reaction. Cycloguanil selectively inhibits the bifunctional dihydrofolate reductase-thymidylate synthase (DHFR-TS) of plasmodium parasite, thereby disrupting deoxythymidylate synthesis and ultimately blocking DNA and protein synthesis in the parasite. 